\title{
Geniposide attenuates cadmium-induced oxidative stress injury via Nrf2 signaling in osteoblasts
}

\author{
TENGFENG HE* , HUASONG SHEN**, JINKE ZHU, YAN ZHU, YAN HE, ZHIWEN LI and HUANXING LU \\ Spine Department, Zhuji People's Hospital, Zhuji, Zhejiang 311800, P.R. China
}

Received May 18, 2018; Accepted November 29, 2018

DOI: $10.3892 / \mathrm{mmr} .2019 .10396$

\begin{abstract}
Geniposide, as a type of iridoid glycoside, has antioxidative capacity. However, the mechanism underlying the effect of geniposide in cadmium (Cd)-induced osteoblast injury remains only partly elucidated. In the present study, Cell Counting Kit-8 (CCK-8) was used to determine MC-3T3-E1 cell viability. Flow cytometry was used to determine the rate of apoptosis and levels of reactive oxygen species (ROS). Oxidative stress-related factors were assessed using enzyme-linked immunosorbent method (ELISA). Quantitative real-time polymerase chain reaction (qPCR) and western blotting were used to evaluate apoptosis- and bone formation-related genes and nuclear factor erythroid 2-related factor (Nrf2) signaling. It was demonstrated that geniposide increased the viability of the Cd-treated MC-3T3-E1 cells. Geniposide decreased apoptosis and ROS accumulation compared to these parameters in the $\mathrm{Cd}$ group. Geniposide attenuated oxidative stress-related factors, malondialdehyde and lactate dehydrogenase and increased antioxidant key enzyme superoxidase dismutase (SOD). The expression levels of Bax, Bcl-2 and survivin were modulated by geniposide. Additionally, the mRNA and protein expression of the receptor activator of $N F-\kappa B$ ligand (RANKL) and osterix were significantly increased, while osteoprotegerin was decreased by geniposide treatment compared to the $\mathrm{Cd}$ groups. Geniposide also enhanced Nrf2, heme oxygenase-1 (HO-1) and NAD(P)H quinone dehydrogenase 1 (NQO1) expression. The present study identified a potential agent for the treatment of Cd-induced osteoblast injury.
\end{abstract}

\section{Introduction}

Cadmium, an environmental pollutant, seriously affects public health worldwide. A large number of studies have shown that

Correspondence to: Dr Huanxing Lu, Spine Department, Zhuji People's Hospital, 9 Jianmin Road, Taozhu, Zhuji, Zhejiang 311800, P.R. China

E-mail: huanxinllu@163.com

${ }^{*}$ Contributed equally

Key words: geniposide, cadmium-induced, osteoblast, oxidative stress, Nrf2 signaling cadmium exerts multi-organ and multi-system toxicity, and that it is able to produce carcinogenic, orthodontic and mutagenic effects, for example, muscle wastage, hemolysis, immunosuppression, and a decrease in fertility (1-4). 'Itai-itai' disease was first known to the world after mining-related cadmium poisoning in Japan in $1955(5,6)$. Bone is a main target organ for cadmium toxicity. Previous studies have indicated that cadmium may damage osteoblasts in culture by decreasing bone calcium and prostaglandin 2 (PGE2) levels (7-9). It has also been confirmed that cadmium affects bone metabolism both directly and indirectly (10). Researchers also demonstrated that the osteotoxicity of cadmium may be caused by alterations to vitamin D metabolism and disruption of the balance of calcium absorption and excretion $(11,12)$. Moreover, cadmium damage directly increases the risk of bone fracture and osteoporosis, and cadmium can affect the activation of osteoclasts and osteoblasts, leading to imbalance between bone resorption and formation (13-18).

Under normal circumstances, the body or cells constantly produce free radicals, while the antioxidant system scavenges these free radicals. Such a dynamic balance maintains a stable metabolism in contrast to the condition in which an imbalance would cause free radical accumulation and lipid peroxidation (19). Cadmium not only induces the initiation of oxidative damage, produces lipid peroxide, destroys the intracellular state of redox equilibrium, but also interferes with the function of the antioxidant system. Cadmium mainly mediates oxidative stress through an indirect reaction pathway, largely by reducing the level of antioxidants in cells and mediating mitochondrial functional damage, increasing the production of reactive oxygen species (ROS) (20-23). Therefore, the toxic effects of cadmium on osteoblasts may be the result of oxidative stress and ROS levels.

Geniposide, a type of iridoid glycoside, is the main active component of Gardenia jasminoides (Rubiaceae). Geniposide is considered to have anti-inflammatory, antioxidant activity as well as antitumor properties (24-28). Researchers have reported that geniposide also exhibits effects on brain by reducing inflammatory response of microglial cells and protecting the neural tissue from cerebral ischemia $(29,30)$; and on digestive system diseases, namely by suppressing helicobacter pylori infections (31). Geniposide activates osteoblasts to facilitate osteogenesis, and suppresses osteoclast activity and inhibits bone resorption (32). In addition, geniposide may promote the growth of osteoblast MC3T3-E1 cells, and suppress 
$\mathrm{H}_{2} \mathrm{O}_{2}$-induced apoptosis (33). To the best of our knowledge, current investigations have focused heavily on the antioxidative capacity of geniposide. Recent studies have shown that geniposide protected PC12 cells from oxidative damage through its radical scavenging activity $(34,35)$. Geniposide was also found to protect against oxygen and glucose deprivation-induced neuronal cell death in rat hippocampal slice cultures (36). Thus, it was speculated that geniposide may protect osteoblasts from oxidative stress induced by cadmium.

The present study aimed to determine the protective effects of geniposide against cadmium-induced osteoblast (MC-3T3-E1) injury, and to investigate its underlying protective mechanisms with a focus on oxidative stress.

\section{Materials and methods}

Reagents. Geniposide (purity $>98 \%$ ) was purchased from Pure-one Bio Technology, Co., Ltd (Shanghai, China). Geniposide was dissolved in water, $\mathrm{pH}$ 7.4. Cadmium chloride $\left(\mathrm{CdCl}_{2}\right)$ was purchased from Sigma-Aldrich; Merck KGaA (Darmstadt, Germany).

Cell culture and morphological observation. Rat MC-3T3-E1 cells (Riken Cell Bank, Tsukuba, Ibaraki, Japan) were cultured in Dulbecco's modified Eagle's medium (DMEM; Thermo Fisher Scientific, Inc., Waltham, MA, USA) with $10 \%$ (v/v) fetal bovine serum (Gibco; Thermo Fisher Scientific, Inc.) and $100 \mathrm{U} / \mathrm{ml}$ penicillin (or $100 \mu \mathrm{g} / \mathrm{ml}$ streptomycin) in a $37^{\circ} \mathrm{C}$ incubator with $5 \% \mathrm{CO}_{2}$ humidified atmosphere. The morphology of primary cultured MC-3T3-E1 cells was observed using an inverted microscope $(\mathrm{x} 40)$.

Cell Counting Kit-8 (CCK-8) assay. The CCK-8 assay kit (Beyotime Institute of Biotechnology, Haimen, China) was used to measure cell viability. MC-3T3-E1 cells $\left(5 \times 10^{3}\right.$ cells/well) were cultured in 96-well plates and were treated with $\mathrm{CdCl}_{2}$ $(0-20 \mu \mathrm{M})$. Geniposide $(100,200$ and $400 \mu \mathrm{g} / \mathrm{ml})$ was used as previously described (37) to treat the cells in order to detect its effect on $\mathrm{CdCl}_{2}$-induced injury.

For the cell viability assay, $10 \mu \mathrm{l}$ CCK- 8 solution was added into each well, and the cells were incubated for another $3 \mathrm{~h}$ at $37^{\circ} \mathrm{C}$. Cell viability was determined using a microplate reader as previously described (38) by reading the optical density at a wavelength of $450 \mathrm{~nm}$, and at a reference wavelength of $630 \mathrm{~nm}$.

Flow cytometry. Cell apoptosis was detected in MC-3T3-E1 cell cultures using a flow cytometer. The cells were harvested and re-suspended in Annexin binding buffer at $1 \times 10^{5}$ cells $/ \mathrm{ml}$. Then, the suspension was incubated with Annexin V-FITC and propidium iodide (PI) [cat. no. 70-AP101-60; MultiSciences (Lianke) Biotech Co., Ltd., Hangzhou, China] in the dark for $15 \mathrm{~min}$ at $4^{\circ} \mathrm{C}$. The apoptosis of the cell samples was analyzed by flow cytometry with BD CellQuest Pro Software version 1.2 (BD Biosciences, San Jose, CA, USA).

The ROS levels were measured using 2',7'-dichlorodihydrofluorescein diacetate (DCFH-DA) as previously described (39). DCFH-DA (Sigma-Aldrich; Merck KGaA), without fluorescence, can enter the cell membrane and form DCFH in the cell. DCFH is then oxidized to form a fluorescent substance DCF in the presence of ROS. MC-3T3-E1 cells were stained with DCFDA and held for $30 \mathrm{~min}$ at room temperature. Finally, DCF fluorescence levels were measured by flow cytometry and the data were analyzed using Summit Software (version 4.3; Dako; Agilent Technologies, Inc., Santa Clara, CA, USA).

Enzyme-linked immunosorbent assay (ELISA). Oxidative stress-related factors malondialdehyde (MDA; cat. no. m1077384; Enzyme-linked Biotechnology Co., Ltd., Shanghai, China), lactate dehydrogenase (LDH; cat. no. m1076593; Enzyme-linked Biotechnology Co., Ltd.) and superoxidase dismutase (SOD; cat. no. m1077379; Enzyme-linked Biotechnology Co., Ltd.) were measured using ELISA. MC-3T3-E1 cells were seeded on a 24-well plate, and cell-free supernatants were harvested after $3 \mathrm{~h}$. The concentrations of MDA, LDH and SOD in the supernatants of MC-3T3-E1 cells were determined using ELISA kits following the manufacturer's instructions.

Reverse transcription-quantitative polymerase chain reaction $(R T-q P C R)$. RT-qPCR was performed for the purpose of examining gene expression profiles of Bax, Bcl-2, survivin, NF- $\mathrm{KB}$ ligand (RANKL), osteoprotegerin (OPG), osterix, nuclear factor erythroid 2-related factor (Nrf2), heme oxygenase-1 (HO-1) and $\mathrm{NAD}(\mathrm{P}) \mathrm{H}$ quinone dehydrogenase 1 (NQO1). Total RNA was extracted using TRIzol ${ }^{\circledR}$ regent (Invitrogen; Thermo Fisher Scientific, Inc.) following the manufacturer's instructions. RNA was reverse transcribed into cDNA using GoScript $^{\mathrm{TM}}$ RT kit (Promega Corporation, Madison, WI, USA). The RT temperature protocol consisted of $37^{\circ} \mathrm{C}$ for $15 \mathrm{~min}$ and at $85^{\circ} \mathrm{C}$ for $5 \mathrm{sec}$. RT-qPCR was conducted using SYBR Fast qPCR Mix (Invitrogen; Thermo Fisher Scientific, Inc.) The thermocycling conditions were: $94^{\circ} \mathrm{C}$ for $3 \mathrm{~min}$ for an initial denaturation, followed by 30 denaturation cycles at $94^{\circ} \mathrm{C}$ for $5 \mathrm{sec}$, annealing and elongation at $60^{\circ} \mathrm{C}$ for $30 \mathrm{sec}$; and final extension at $72^{\circ} \mathrm{C}$ for $10 \mathrm{~min}$. The primer sequences are summarized in Table I. The quantity of RNA was calculated using the $2^{-\Delta \Delta \mathrm{Cq}}$ method (40), and the level of expression of an RNA was normalized to GAPDH (denoted 'relative expression').

Western blot analysis. MC-3T3-E1 cells were washed three times with PBS, and detached from the dishes by scraping. Cells were centrifuged at $12,000 \mathrm{x}$ g for $5 \mathrm{~min}$ at $4^{\circ} \mathrm{C}$ and re-suspended in RIPA lysis buffer (Thermo Fisher Scientific, Inc.) with phenylmethanesulfonyl fluoride (PMSF) at 1:200 dilution. The homogenate was centrifuged at $12,000 \mathrm{x} \mathrm{g}$ for $10 \mathrm{~min}$ at $4^{\circ} \mathrm{C}$. Protein concentrations were quantified using a bicinchoninic acid protein assay kit (Beyotime Institute of Biotechnology). Equivalent amounts of total protein $(20 \mu \mathrm{g} /$ lane $)$ were loaded on a $10 \%$ Tris-glycine, $10 \%$ SDS-PAGE (Beyotime Institute of Biotechnology) for separation. Proteins were then transferred onto a polyvinylidene difluoride membrane, which were blocked with $5 \%$ milk in TBS containing $0.2 \%$ Tween-20 (TBST) at room temperature for $2 \mathrm{~h}$, and incubated with primary antibodies as follows: Rabbit anti-Bcl-2 (cat. no. ab32124, 1:1,000) anti-Bax (cat. no. ab32503, 1:1,000), anti-survivin (cat. no. ab76424, 1:1,000); rabbit anti-RANKL (cat. no. ab9957, 1:1,000), anti-OPG (cat. 
Table I. Primer sequences.

\begin{tabular}{|c|c|}
\hline Gene & Primer sequence $\left(5^{\prime}-3^{\prime}\right)$ \\
\hline Bax & $\begin{array}{l}\text { Forward: TTCATCCAGGATCGAGCAGAG } \\
\text { Reverse: TGAGGACTCCAGCCACAAAGAT }\end{array}$ \\
\hline Bcl-2 & $\begin{array}{l}\text { Forward: CTGGTGGACAACATCGCTCTG } \\
\text { Reverse GGTCTGCTGACCTCACTTGTG }\end{array}$ \\
\hline Survivin & $\begin{array}{l}\text { Forward: CCCTGCCTGGCAGCCCTTTC } \\
\text { Reverse: CTGGCTCCCAGCCTTCCA }\end{array}$ \\
\hline$R A N K L$ & $\begin{array}{l}\text { Forward: TCGGGTTCCCATAAAGTC } \\
\text { Reverse: GAAGCAAATGTTGGCGTA }\end{array}$ \\
\hline$O P G$ & $\begin{array}{l}\text { Forward: GCAGCATCGCTCTGTTCCTGTA } \\
\text { Reverse: ATGGTGGTGAAGACGCCAGTA }\end{array}$ \\
\hline Osterix & $\begin{array}{l}\text { Forward: GCCTACTTACCCGTCTGACTTT } \\
\text { Reverse: GCCCACTATTGCCAACTGC }\end{array}$ \\
\hline$N r f 2$ & $\begin{array}{l}\text { Forward: GCCAGCTGAACTAATTAGAC } \\
\text { Reverse: GATTCGTGCACAGCAGCA }\end{array}$ \\
\hline $\mathrm{HO}-1$ & $\begin{array}{l}\text { Forward: TTGTCTCTCTGGAATGGAAGG } \\
\text { Reverse: CTCTACCGACCATTCTG }\end{array}$ \\
\hline$N Q O 1$ & $\begin{array}{l}\text { Forward: CATTCTGAAAGGCTGGTTTGA } \\
\text { Reverse: CTAGCTTTGATCTGGTTGTCAG }\end{array}$ \\
\hline$G A P D H$ & $\begin{array}{l}\text { Forward: GGCACAGTCAAGGCTGAGAATG } \\
\text { Reverse: ATGGTGGTGAAGACGCCAGTA }\end{array}$ \\
\hline
\end{tabular}

no. ab73400, 1:1,000), anti-osterix (cat. no. ab94744, 1:1,000); mouse anti- HO-1 antibody (ab13248, 1:1,000), NQO1 antibody (ab34173, 1:1,000), Nrf2 antibody (ab137550, 1:1,000) and anti-GAPDH (ab9485, 1:1,000) overnight at $4^{\circ} \mathrm{C}$, all purchased from Abcam (Cambridge, UK). The membranes were washed with TBST, and then incubated with horseradish peroxidase-conjugated secondary antibodies goat anti-rabbit (cat. no. ab205718; 1:2,000; Abcam) and goat anti-mouse (cat. no. ab205719; 1:5,000; Abcam) at $4^{\circ} \mathrm{C}$ for $1 \mathrm{~h}$. The blots were visualized using enhanced chemiluminescence (ECL; Thermo Fisher Scientific, Inc.). An ECL system (Amersham; GE Healthcare, Chicago, IL, USA) was used to detect the bands. Quantity one software version 4.6.2 (Bio-Rad Laboratories, Inc., Hercules, CA, USA) was used for densitometry analysis.

Statistical analysis. GraphPad Prism version 6.0 software (GraphPad Software, Inc., La Jolla, CA, USA) was used for conducting statistical analysis. Data are presented as the mean \pm standard deviation. Statistical significance was analyzed using one-way analysis of variance, followed by Turkey's multiple comparison test. $\mathrm{P}<0.05$ was considered to indicate a statistically significant difference.

\section{Results}

Morphological observation of MC-3T3-E1 osteoblasts. After MC-3T3-E1 cells were inoculated and cultured for $24 \mathrm{~h}$, the growth of adherent cells was observed using an inverted microscope (Fig. 1A). The cells showed a fibroblast-like appearance. To be more specific, the cells appeared to be irregular fusi-formed, triangular, or polygonal, and no fusion between cells was identified. As the duration of the culture time prolonged, cell bodies grew larger and the cell morphology was stretched. It appeared fiber bundles, triangles and polygons with more protuberances. Some elongated protuberances were often found to link cells with distant protuberant cells and to increase cell-to-cell contact. Meanwhile, the number of cells was found to increase, and cells were mostly spindle-shaped or cubic.

Protective effect of geniposide on $\mathrm{CdCl}_{2}$-injured $\mathrm{MC}$-3T3-EI cells. The cytotoxic effects of different $\mathrm{CdCl}_{2}$ concentrations $(0-20 \mu \mathrm{M})$ at different time points $(3,6,12$ and $24 \mathrm{~h})$ in MC-3T3-E1 cells were determined using CCK-8 assay. The results showed that $\mathrm{CdCl}_{2}$ decreased $\mathrm{MC}-3 \mathrm{~T} 3-\mathrm{E} 1$ cell viability in time- and dose-dependent manners $(20 \mu \mathrm{M}, 3 \mathrm{~h}, \mathrm{P}<0.05$; $20 \mu \mathrm{M}, 24 \mathrm{~h}, \mathrm{P}<0.01$; Fig. 1B). Based on this findings, $20 \mu \mathrm{M}$ of $\mathrm{CdCl}_{2}$ was employed in all subsequent experiments. Moreover, the cytotoxic effects of geniposide were also detected, and that geniposide had no cytotoxic effects at a concentration of 100-400 $\mu \mathrm{g} / \mathrm{ml}$ (Fig. 1C). As showed in Fig. 1D, geniposide was able to ameliorate the $\mathrm{CdCl}_{2}$ injury in cells and increase viability in a dose-dependent manner, and treatment using $400 \mu \mathrm{g} / \mathrm{ml}$ geniposide significantly increased cell viability $(\mathrm{P}<0.05)$.

Geniposide decreases the apoptosis induced by $\mathrm{CdCl}_{2}$ in MC-3T3-E1. As showed in Fig. 2A, the effect of geniposide on $\mathrm{CdCl}_{2}$-induced apoptosis was investigated using flow cytometric analysis. We found that the apoptosis induced by $\mathrm{CdCl}_{2}$ was significantly decreased in a concentration-dependent manner after being pretreated with geniposide (100 and $200 \mu \mathrm{g} / \mathrm{ml}: \mathrm{P}<0.05,400 \mu \mathrm{g} / \mathrm{ml}: \mathrm{P}<0.01)$.

Geniposide decreases the ROS level in $\mathrm{CdCl}_{2}$-injured MC-3T3-E1 cells. As showed in Fig. $2 \mathrm{~B}, \mathrm{CdCl}_{2}$ exposure increased the ROS generation in MC-3T3-E1 cells $(\mathrm{P}<0.01)$. However, pretreatment of MC-3T3-E1 cells with geniposide significantly decreased the generation of ROS in a dose-dependent manner $(\mathrm{P}<0.01)$.

Geniposide affects MDA, LDH and antioxidant enzyme SOD activities in $\mathrm{CdCl}_{2}$-injured $\mathrm{MC}$-3T3-E1 cells. As shown in Fig. 3, the effects of geniposide on $\mathrm{CdCl}_{2}$-induced oxidative stress-related factors were assessed using ELISA assay. We found that the level of MDA was not significantly increased by exposure of the cells to $\mathrm{CdCl}_{2}$, and that pretreatments at different concentrations of geniposide also showed no significant effect on the level of MDA ( $>>0.05$, Fig. 3A). However, $\mathrm{LDH}$ was significantly increased following exposure of the cells with $\mathrm{CdCl}_{2}$. By contrast, a medium concentration of geniposide pretreatment significantly decreased the level of $\mathrm{LDH}$, compared to the cells incubated with $\mathrm{CdCl}_{2}(\mathrm{P}<0.05$, Fig. 3B). Our results also showed that antioxidant key enzyme SOD was decreased following $\mathrm{CdCl}_{2}$ exposure, but SOD was significantly higher following pretreatment with a high concentration of geniposide $(\mathrm{P}<0.05$, Fig. 3C).

Geniposide regulates the expression of Bax, Bcl-2 and survivin at the $m R N A$ and protein levels of $\mathrm{CdCl}_{2}$-injured MC-3T3-E1 cells. We determined the expression levels of Bax, Bcl-2 and survivin in MC-3T3-E1 cells using both western blotting and qPCR analyses. As shown in 
A

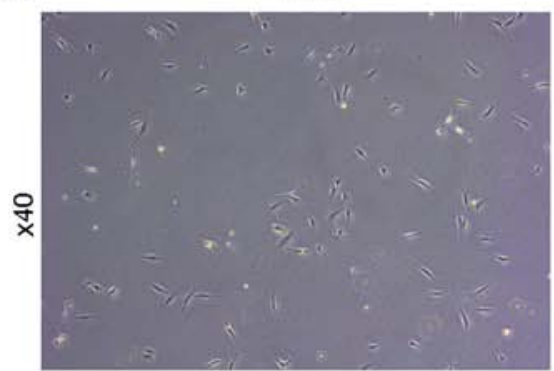

$48 \mathrm{~h}$

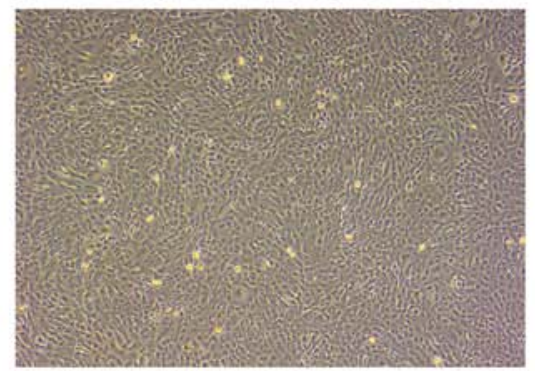

$72 \mathrm{~h}$

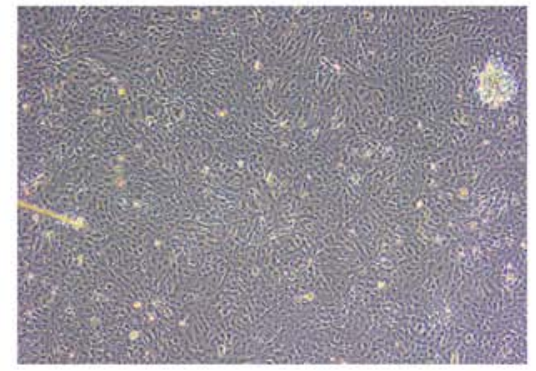

B

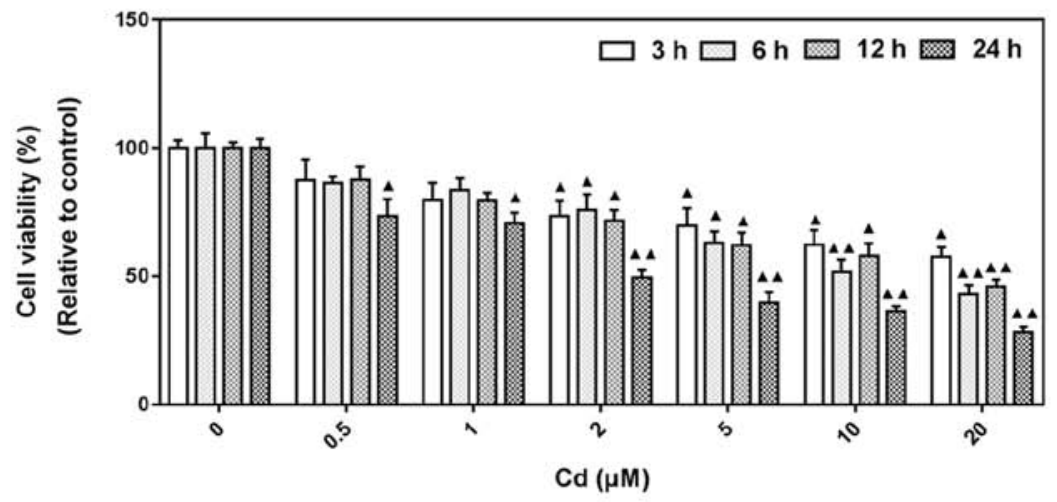

C

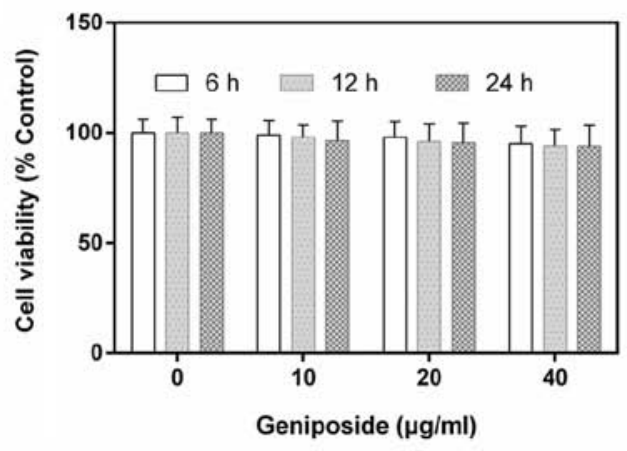

D

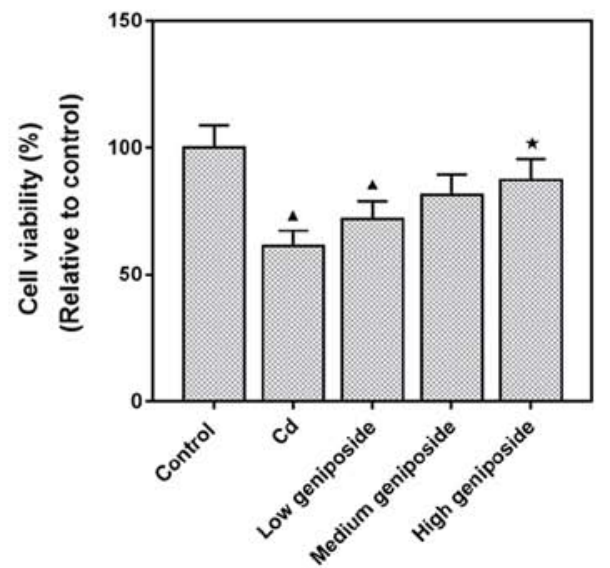

Figure 1. Effects of different concentrations of geniposide on $\mathrm{CdCl}_{2}(\mathrm{Cd})$-induced toxic injury of $\mathrm{MC}-3 \mathrm{~T} 3$-E1 cells. Cell viability was assessed by the CCK-8 assay. (A) The morphology of primary cultured MC-3T3-E1 cells was observed at 24, 48 and $72 \mathrm{~h}$ using an inverted microscope (x40 magnification). (B) The cytotoxic effects of different concentrations and different exposure times of $\mathrm{CdCl}_{2}$ on $\mathrm{MC}-3 \mathrm{~T} 3$-E1 cells. (C) The cytotoxic effects of different concentrations and different treatment times of geniposide in MC-3T3-E1 cells. (D) Geniposide protects $\mathrm{MC}^{-3 T 3-E 1 ~ c e l l s ~ f r o m ~ C d C l}{ }_{2}$-induced toxic injury. Cells were pretreated with geniposide [100 (low), 200 (medium) and $400 \mu \mathrm{g} / \mathrm{ml}$ (high)] for $24 \mathrm{~h}$ before being exposed to $20 \mu \mathrm{M} \mathrm{CdCl}$, after a continued culture for $3 \mathrm{~h}$. Data were expressed as the mean \pm standard deviation from three independent experiments. ${ }^{\boldsymbol{\Delta}} \mathrm{P}<0.05$ and ${ }^{\boldsymbol{\Lambda}} \mathrm{P}<0.01$, compared with the control; ${ }^{*} \mathrm{P}<0.05$, compared with $\mathrm{CdCl}_{2}$ alone.

Fig. 3D-G, compared with levels in cells exposed to $\mathrm{CdCl}_{2}$, pretreatment with geniposide increased the expression of Bcl-2 and survivin both at mRNA and protein levels in a concentration-dependent manner (survivin, $200 \mu \mathrm{g} / \mathrm{ml}$ $\mathrm{P}<0.05 ; 400 \mu \mathrm{g} / \mathrm{ml} \mathrm{P}<0.01)$ and reduced the expression of Bax at the mRNA and protein levels $(400 \mu \mathrm{g} / \mathrm{ml}, \mathrm{P}<0.01)$. Both western blot and qPCR analysis showed that medium and high concentrations of geniposide could inhibit Bax, and increase Bcl-2 and survivin. These results showed that geniposide strongly antagonized the apoptotic process of $\mathrm{CdCl}_{2}$-induced MC-3T3-E1 cells.

Geniposide regulates the expression of $R A N K L, O P G$ and osterix at both the $m R N A$ and protein levels in $\mathrm{CdCl}_{2}$-injured
MC-3T3-E1 cells. In order to investigate whether geniposide could reverse the inhibition of $\mathrm{CdCl}_{2}$ on osteoblast formation, we assessed the expression of osteoblast-related factors, RANKL, OPG and osterix, by carrying out western blot and qPCR analyses in MC-3T3-E1 cells. The results showed that exposure to $\mathrm{CdCl}_{2}$ significantly inhibited osteoblast formation by increasing the expression of OPG and by decreasing the expression of RANKL and osterix both at the mRNA and protein levels. Medium concentration of geniposide significantly reversed of the inhibition mediated by $\mathrm{CdCl}_{2}$ on osteoblast formation through upregulating the expression of RANKL and osterix $(\mathrm{P}<0.01)$ and downregulating the expression of OPG $(\mathrm{P}<0.05)$. The protein levels (Fig. 4A-C) were consistent with the expression of mRNA (Fig. 4D). 

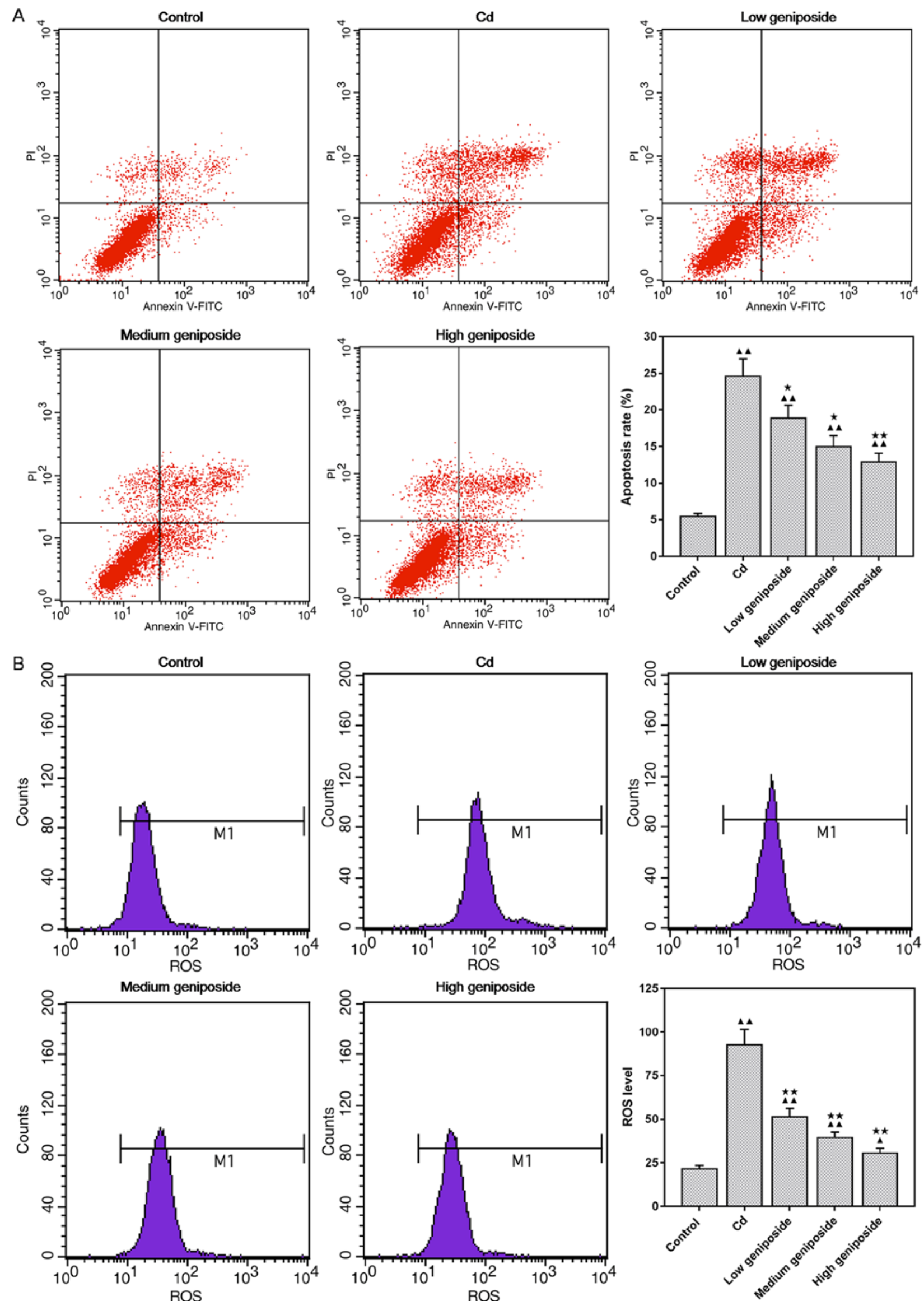

Figure 2. Effects of different concentrations of geniposide on $\mathrm{CdCl}_{2}(\mathrm{Cd})$-induced apoptosis and reactive oxygen species (ROS) level in MC-3T3-E1 cells analyzed by flow cytometry. Cells were pretreated with geniposide [100 (low), 200 (medium) and $400 \mu \mathrm{g} / \mathrm{ml}$ (high)] for $24 \mathrm{~h}$, followed by exposure to CdCl ${ }_{2}$ $(20 \mu \mathrm{M})$ for $3 \mathrm{~h}$. (A) The apoptotic rate by flow cytometry. (B) ROS levels were analyzed using flow cytometry. Each point represents the mean \pm standard deviation from three independent experiments. ${ }^{\boldsymbol{\Delta}} \mathrm{P}<0.05$ and ${ }^{\boldsymbol{\Lambda}}{ }^{\boldsymbol{}} \mathrm{P}<0.01$, compared with the control; ${ }^{*} \mathrm{P}<0.05$ and ${ }^{* *} \mathrm{P}<0.01$, compared with $\mathrm{CdCl} \mathrm{l}_{2}$ alone. 
A

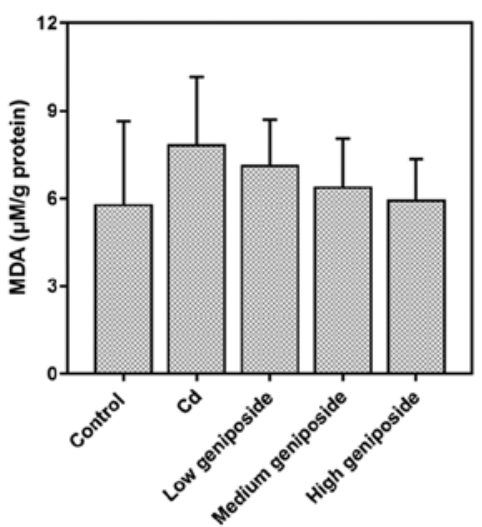

D

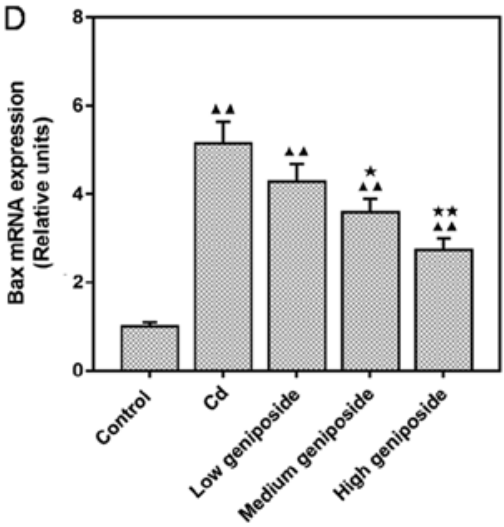

$\mathrm{B}$
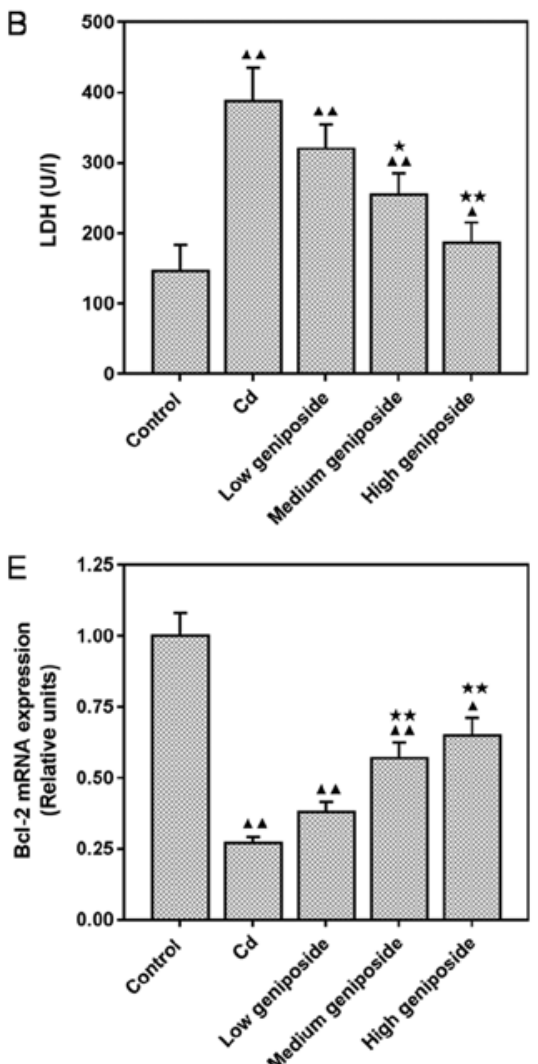

C
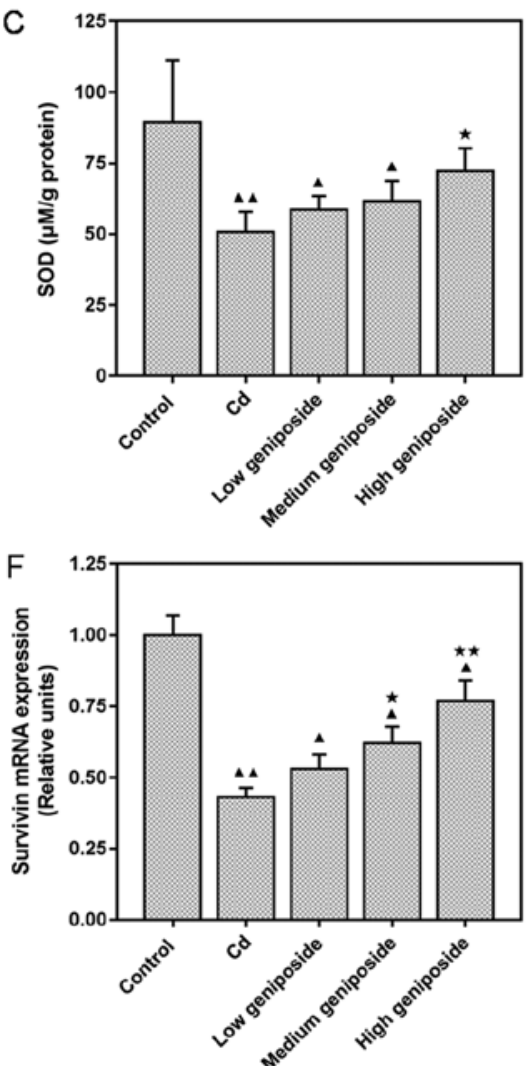

G

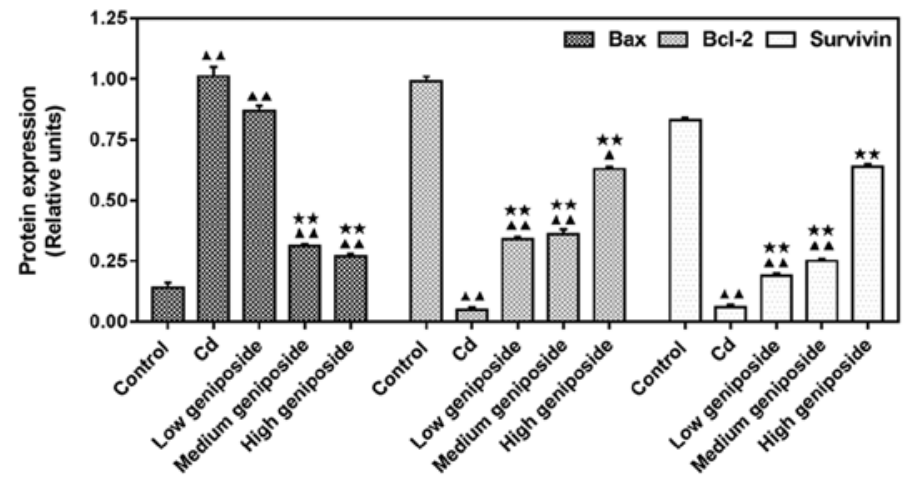

Figure 3. Effects of different concentrations of geniposide on $\mathrm{CdCl}_{2}(\mathrm{Cd})$-induced expression of MDA, LDH and SOD and the mRNA and protein levels of Bax, Bcl-2 and survivin. Cells were pretreated with geniposide [100 (low), 200 (medium), $400 \mu \mathrm{g} / \mathrm{ml}$ (high)] for $24 \mathrm{~h}$, followed by exposure to CdCl $\mathrm{C}_{2}(20 \mu \mathrm{M}$ ) for $3 \mathrm{~h}$. (A-C) Oxidative stress-related factors (MDA, LDH, SOD) were assessed by ELISA assay. (D-F) Reverse transcription-quantitative PCR was used to determine the mRNA expression of Bax, Bcl-2 and survivin. (G) Western blotting results and relative units of protein levels. Expression of each protein in the control or geniposide-pretreated MC-3T3-E1 cells following normalization with a loading control GAPDH. Data are expressed as the mean \pm standard deviation from three independent experiments. ${ }^{\mathbf{\Delta}} \mathrm{P}<0.05$ and ${ }^{\boldsymbol{\Delta} \mathbf{\Delta}} \mathrm{P}<0.01$, compared with the control; ${ }^{*} \mathrm{P}<0.05$ and ${ }^{* * *} \mathrm{P}<0.01$, compared with $\mathrm{CdCl} \mathrm{a}_{2}$ alone. $\mathrm{MDA}$, malondialdehyde; LDH, lactate dehydrogenase; SOD, superoxidase dismutase.

Geniposide regulates the downstream target genes of $\mathrm{Nrf} 2$ at both the mRNA and protein levels in $C_{C l} C_{2}$-injured $M C$-3T3-EI cells. In order to understand the mechanism of geniposide in Cd-induced osteoblast injury, the Nrf2 signaling pathway was evaluated in MC-3T3-E1 cells. As shown in Fig. 5, both qPCR and western blot analysis identified an increase in Nrf2, HO-1 and NQO1 expression in a dose-dependent manner following pretreatment with geniposide in the $\mathrm{CdCl}_{2}$-injured MC-3T3-E1 cells. We found that a low concentration of geniposide significantly increased the mRNA expression of $\mathrm{Nrf} 2$ in comparison to that in cells exposed to $\mathrm{CdCl}_{2}(\mathrm{P}<0.05$, Fig. 5A). However, both the increase of HO-1 and NQO1 mRNA expression required treatment with a medium concentration of geniposide
$(\mathrm{P}<0.05$, Fig. 5B and $\mathrm{C})$. Western blot analyses also showed that a low concentration of geniposide increased the protein expression of Nrf2, HO-1 and NQO1 compared to that in cells exposed only to $\mathrm{CdCl}_{2}(\mathrm{P}<0.01$, Fig. 5D).

\section{Discussion}

In the present study, osteoblast MC-3T3-E1 cells were pretreated with three different concentrations (100, 200 and $400 \mu \mathrm{g} / \mathrm{ml}$ ) of geniposide for $24 \mathrm{~h}$, and exposed to $20 \mu \mathrm{M}$ $\mathrm{CdCl}_{2}$ for additional $3 \mathrm{~h}$. Furthermore, qPCR and western blot analysis showed that geniposide at a high concentration was able to significantly enhance the cell viability, while a low 

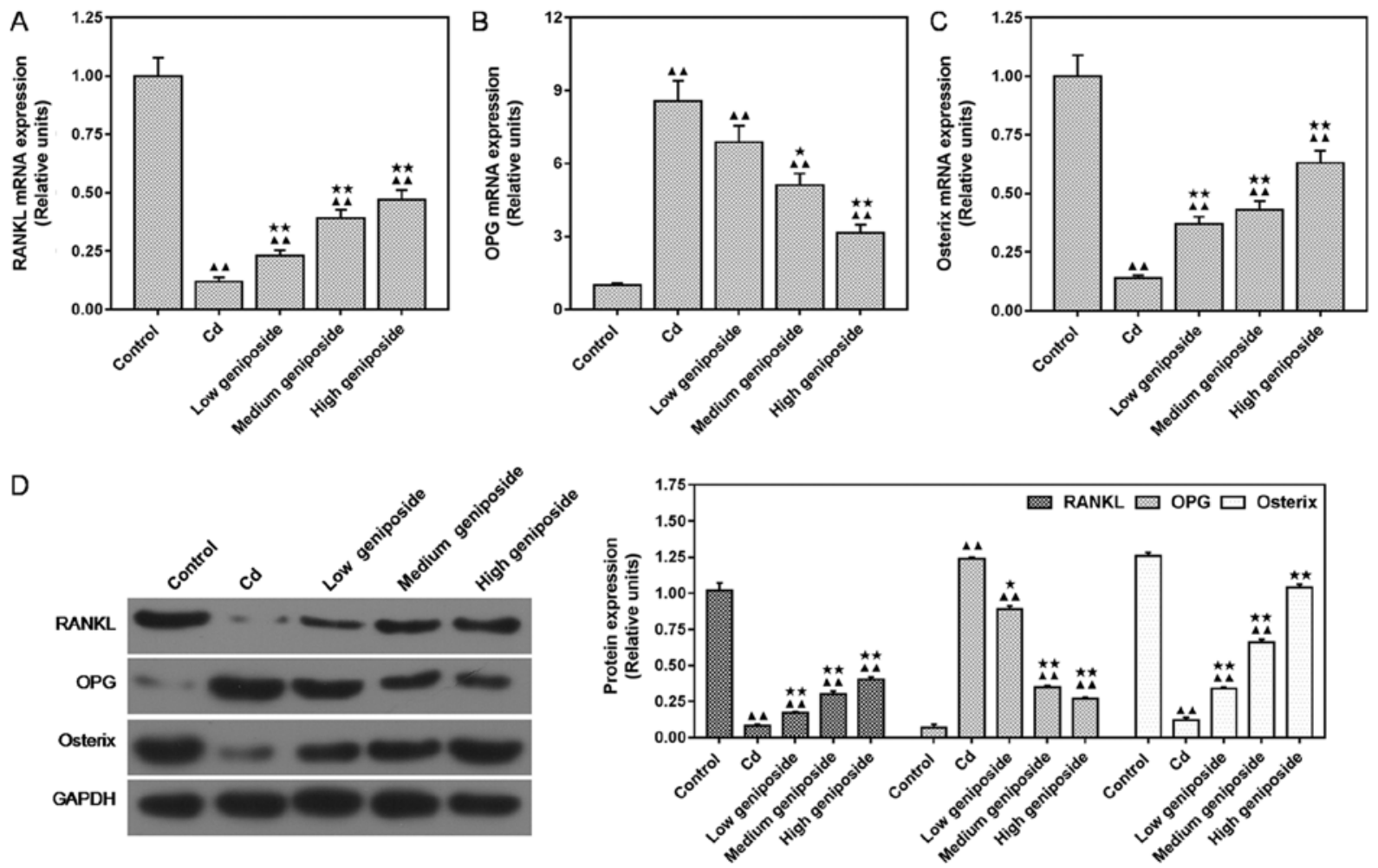

Figure 4. Effects of different concentrations of geniposide on $\mathrm{CdCl}_{2}(\mathrm{Cd})$-induced mRNA and protein levels of osteoblast-related factors RANKL, OPG and osterix. Cells were pretreated with geniposide [100 (low), 200 (medium), $400 \mu \mathrm{g} / \mathrm{ml}$ (high)] for $24 \mathrm{~h}$, followed by exposure to $\mathrm{CdCl}_{2}(20 \mu \mathrm{M})$ for $3 \mathrm{~h}$ (A-C) qPCR was used to determine the mRNA expression of RANKL, OPG and osterix. (D) Western blotting results and relative units of protein levels. Expression of each protein in control or geniposide-pretreated MC-3T3-E1 cells following normalization with a loading control GAPDH. Data are shown as the mean \pm standard deviation from three independent experiments. ${ }^{\Delta \Delta} \mathrm{P}<0.01$, compared with the control; ${ }^{*} \mathrm{P}<0.05$ and ${ }^{* *} \mathrm{P}<0.01$, compared with CdCl ${ }_{2}$ alone. RANKL, receptor activator of NF- $\mathrm{KB}$ ligand.
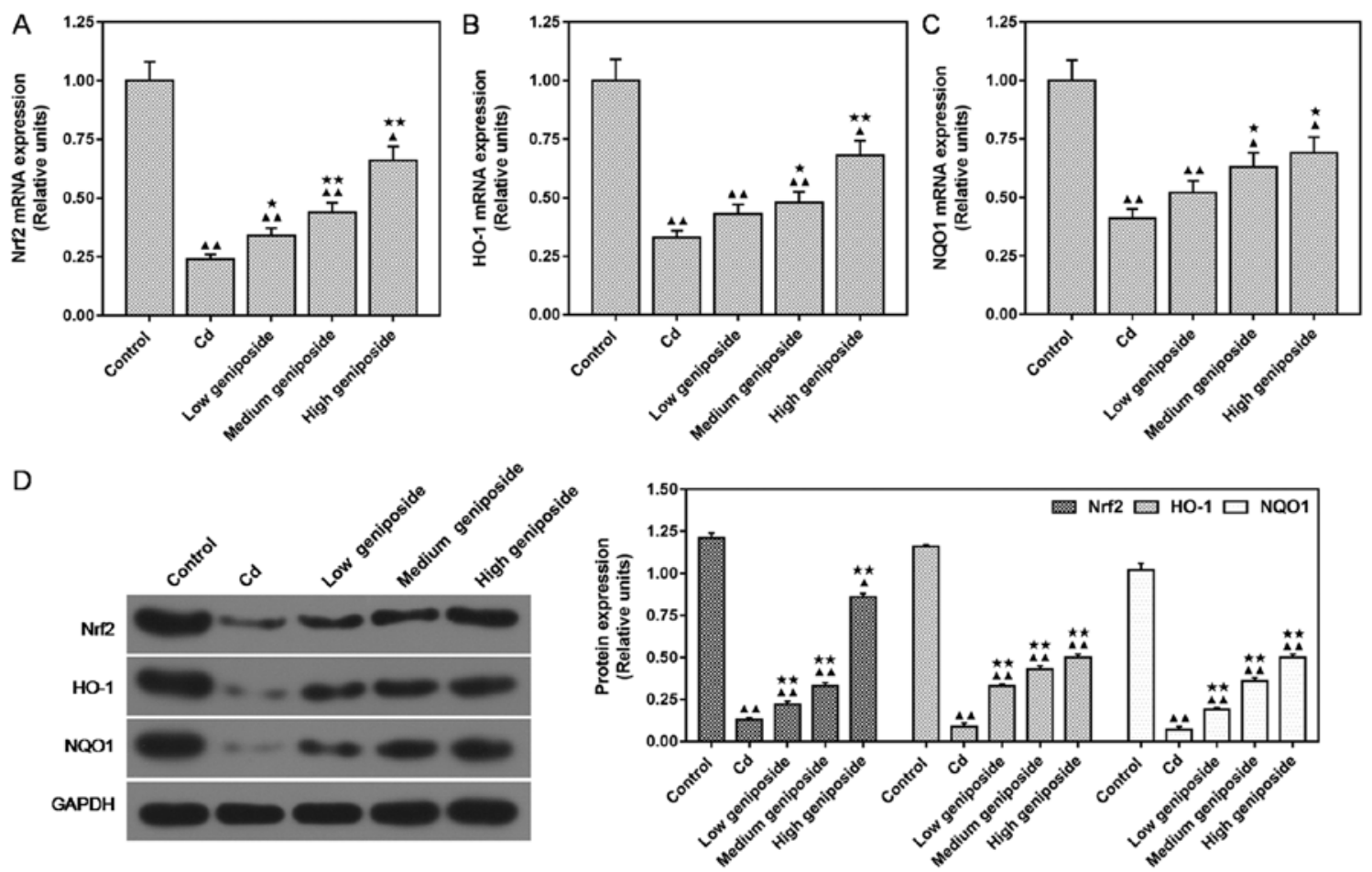

Figure 5. Effects of different concentrations of geniposide on $\mathrm{CdCl}_{2}(\mathrm{Cd})$-induced mRNA and protein levels of Nrf2, $\mathrm{HO}-1$ and NQO1. Cells were pretreated with geniposide [100 (low), 200 (medium), $400 \mu \mathrm{g} / \mathrm{ml}$ (high)] for $24 \mathrm{~h}$, followed by exposure to $\mathrm{CdCl}_{2}(20 \mu \mathrm{M})$ for $3 \mathrm{~h}$. (A-C) qPCR was used to determine the mRNA expression of Nrf2, HO-1 and NQO1. (D) Western blotting results and relative units of protein levels. Expression of each protein in control or geniposide pretreated MC-3T3-E1 cells following normalization with a loading control GAPDH. Data are expressed as the mean \pm standard deviation from three independent experiments. ${ }^{\boldsymbol{\Lambda}} \mathrm{P}<0.05$ and ${ }^{\boldsymbol{\Lambda}}{ }^{\mathbf{}} \mathrm{P}<0.01$, compared with the control; ${ }^{*} \mathrm{P}<0.05$ and ${ }^{* *} \mathrm{P}<0.01$, compared with $\mathrm{CdCl}_{2}$ alone. $\mathrm{Nrf}^{2}$, nuclear factor erythroid 2-related factor; HO-1, heme oxygenase-1; NQO1, NAD(P)H quinone dehydrogenase 1. 
concentration of geniposide could antagonize apoptosis by downregulating Bax and upregulating both Bcl-2 and survivin.

Furthermore, we found that geniposide could reverse the injury of $\mathrm{CdCl}_{2}$ on osteoblast formation, which is consistent with another study in which geniposide promoted osteoblast formation (33). As previously reported, the RANKL/RANK/OPG system is an important signal transduction pathway in the process of bone metabolism. The receptor activator of $\mathrm{RANKL}$ with its cognate receptor (RANK) promotes differentiation and bone resorption activity of osteoclasts. OPG can also combine RANK, disrupting the balance of bone metabolism $(17,41,42)$. It has been suggested that cadmium can accumulate in human osteoblast-like MG-63 cells and affect their viability, and that high concentrations of cadmium could inhibit bone formation via the OPG/RANKL pathway $(17,43)$. However, a limited number of studies have focused on geniposide in relation to RANKL and OPG in osteoblast cells. In the present study, we demonstrated that low-dose geniposide obviously increased expression of RANKL, and that a medium-dose could decrease expression of OPG. Osterix is a novel transcription factor in the differentiation of osteoblasts, and it is specifically expressed in all developing bones (44). Geniposide promotes osteogenic activity of osteoblasts by increasing the expression of osterix in a dose-dependent manner. It was indicated that geniposide promoted the balance of bone metabolism.

Occupational cadmium exposure and domestic cadmium pollution seriously affect the health of individuals worldwide, causing neuronal damage, cardiovascular effects, reproductive toxicity and osteoblast injury $(4,7,45,46)$. A large amount of evidence has confirmed that reducing internal oxidative stress and increasing endogenous antioxidant proteins are vital in avoiding cell injury $(26,34,39,47)$. Pan et al (48) highlighted the importance of oxidative stress in cadmium exposure disorder, and many compounds produce protective effects against cadmium-induced oxidative injury, for example, quercetin, catechin and nobiletin (49-51). Geniposide had been reported to protect against cadmium-induced toxic oxidative stress in rat kidney tissue (25). Thus, we concluded that geniposide may prevented cadmium-induced injury.

Reactive oxygen species (ROS) are generally produced in the mitochondria. Excessive exogenous oxidants and certain extreme environments including heavy metal, chemotherapeutic drugs, sodium fluoride lead to the overproduction of ROS (52-54). Over-generated ROS damage proteins, lipids and DNA, ultimately causing cell death or apoptosis. $\mathrm{CdCl}_{2}$ exposure was found to significantly increase ROS generation $(55,56)$. Geniposide was found to noticeably decrease ROS levels, to downregulate LDH and to upregulate antioxidase SOD. In order to understand the protective mechanism of geniposide against oxidative stress injury, we detected the downstream target genes of Nrf2, HO-1 and NQO1. Nrf2, a basic leucine-zipper transcription factor, plays an important role in preventing the development of oxidative stress and is also one of the essential regulators of antioxidative stress genes. The role of Nrf2 has been confirmed using Nrf2 knock-out mice in vivo, and it binds to antioxidant response element (ARE) sites in the promoter of cytoprotective phase II genes to regulate their expression (57-61). Our study showed that geniposide not only completely increased the mRNA and protein expression of Nrf2, but also increased antioxidant protein HO-1 and phase II detoxifying enzyme NQO1. Thus, we inferred that the induction of Nrf2 could promote the downstream genes HO-1 and NQO1 so as to attenuate the oxidative stress reaction. Taken together, our study indicated that geniposide could induce Nrf2, suggesting that the Nrf2 pathway may take part in the progressive effects of geniposide on antioxidative stress.

In conclusion, our finding suggests that geniposide could antagonize oxidative stress caused by $\mathrm{CdCl}_{2}$. Activation of $\mathrm{Nrf} 2$, HO-1 and NQO1 may be associated with the effect of geniposide on MC-3T3-E1 cells. Our study identifies a potential agent for the treatment of cadmium-induced osteoblast injury.

\section{Acknowledgements}

Not applicable.

\section{Funding}

No funding was received.

\section{Availability of data and materials}

The datasets used during the present study are available from the corresponding author upon reasonable request.

\section{Authors' contributions}

TH and HS made substantial contributions to the conception and design of the study. JZ, YZ, HL and YH performed data acquisition, data analysis and interpretation. TH and HS drafted the article, critically revised its intellectual content. All authors read and approved the final version of the manuscript. TH, HS, ZL and HL agreed to be accountable for all aspects of the work and ensuring that questions related to the accuracy or integrity of the work were appropriately investigated and resolved.

\section{Ethics approval and consent to participate}

Not applicable.

\section{Patient consent for publication}

Not applicable.

\section{Competing interests}

The authors declare that they have no competing interests.

\section{References}

1. Sato K, Iwamasa T, Tsuru T and Takeuchi T: An ultrastructural study of chronic cadmium chloride-induced neuropathy. Acta Neuropathol 41: 185-190, 1978.

2. Sakata S, Iwami K, Enoki Y, Kohzuki H, Shimizu S, Matsuda M and Moriyama T: Effects of cadmium on in vitro and in vivo erythropoiesis: Erythroid progenitor cells (CFU-E), iron and erythropoietin in cadmium-induced iron deficiency anemia. Exp Hematol 16: 581-587, 1988. 
3. Blakley BR: Humoral immunity in aged mice exposed to cadmium. Can J Vet Res 52: 291-292, 1988.

4. Saygi S, Deniz G, Kutsal O and Vural N: Chronic effects of cadmium on kidney, liver, testis and fertility of male rats. Biol Trace Elem Res 31: 209-214, 1991

5. Sakamoto M, Itai T and Murata K: Effects of prenatal methylmercury exposure: From minamata disease to environmental health studies. Nihon Eiseigaku Zasshi 72: 140-148, 2017 (In Japanese).

6. Morikawa Y, Nakagawa H, Tabata M, Nishijo M, Senma M, Kitagawa Y, Kawano S, Teranishi $\mathrm{H}$ and Kido T: Study of an outbreak of itai-itai disease. Nihon Eiseigaku Zasshi 46 1057-1062, 1992 (In Japanese).

7. Kong YY, Yoshida H, Sarosi I, Tan HL, Timms E, Capparelli C, Morony S, Oliveira-dos-Santos AJ, Van G, Itie A, et al: OPGL is a key regulator of osteoclastogenesis, lymphocyte development and lymph-node organogenesis. Nature 397: 315-323, 1999.

8. Bhattacharyya MH, Whelton BD, Stern PH and Peterson DP: Cadmium accelerates bone loss in ovariectomized mice and fetal rat limb bones in culture. Proc Natl Acad Sci USA 85: 8761-8765, 1988

9. WHO: Environmental Health Criteria. Cadmium-Environmental Aspects 135:134-136, 1992.

10. Martineau C, Abed E, Medina G, Jomphe LA, Mantha M, Jumarie $\mathrm{C}$ and Moreau R: Involvement of transient receptor potential melastatin-related 7 (TRPM7) channels in cadmium uptake and cytotoxicity in MC3T3-E1 osteoblasts. Toxicol Lett 199: 357-363, 2010.

11. Kawamura J, Yoshida O, Nishino K and Itokawa Y: Disturbances in kidney functions and calcium and phosphate metabolism in cadmium-poisoned rats. Nephron 20: 101-110, 1978.

12. Shinichi S and Kiyoshi N: Effects of vitamin D on calcium and bone metabolism. Clin Calcium 13: 863-868, 2003 (In Japanese).

13. Wang $\mathrm{C}$ and Bhattacharyya $\mathrm{MH}$ : Effect of cadmium on bone calcium and $45 \mathrm{Ca}$ in nonpregnant mice on a calcium-deficient diet: Evidence of direct effect of cadmium on bone. Toxicol Appl Pharmacol 120: 228-239, 1993.

14. Brama M, Politi L, Santini P, Migliaccio S and Scandurra R Cadmium-induced apoptosis and necrosis in human osteoblasts: Role of caspases and mitogen-activated protein kinases pathways. J Endocrinol Invest 35: 198-208, 2012.

15. Wallin M, Barregard L, Sallsten G, Lundh T, Karlsson MK, Lorentzon M, Ohlsson C and Mellström D: Low-level cadmium exposure is associated with decreased bone mineral density and increased risk of incident fractures in elderly men: The MrOS Sweden study. J Bone Miner Res 31: 732-741, 2016.

16. Wilson AK, Cerny EA, Smith BD, Wagh A and Bhattacharyya MH: Effects of cadmium on osteoclast formation and activity in vitro. Toxicol Appl Pharmacol 140: 451-460, 1996.

17. Chen X, Zhu G, Gu S, Jin T and Shao C: Effects of cadmium on osteoblasts and osteoclasts in vitro. Environ Toxicol Pharmacol 28: 232-236, 2009.

18. Coonse KG, Coonts AJ, Morrison EV and Heggland SJ: Cadmium induces apoptosis in the human osteoblast-like cell line Saos-2. J Toxicol Environ Health A 70: 575-581, 2007.

19. Yang CF, Shen HM, Shen Y, Zhuang ZX and Ong CN Cadmium-induced oxidative cellular damage in human fetal lung fibroblasts (MRC-5 cells). Environ Health Perspect 105: 712-716, 1997.

20. Thompson $\mathrm{J}$ and Bannigan J: Cadmium: Toxic effects on the reproductive system and the embryo. Reprod Toxicol 25:304-315, 2008

21. Joseph P: Mechanisms of cadmium carcinogenesis. Toxicol Appl Pharmacol 238: 272-279, 2009.

22. Bertin G and Averbeck D: Cadmium: Cellular effects, modifications of biomolecules, modulation of DNA repair and genotoxic consequences (a review). Biochimie 88: 1549-1559, 2006

23. López E, Arce C, Oset-Gasque MJ, Cañadas S and Gonzalez MP Cadmium induces reactive oxygen species generation and lipid peroxidation in cortical neurons in culture. Free Radic Biol Med 40: 940-951, 2006

24. Koo HJ, Lim KH, Jung HJ and Park EH: Anti-inflammatory evaluation of gardenia extract, geniposide and genipin. J Ethnopharmacol 103: 496-500, 2006.

25. Liu E, Han L, Wang J, He W, Shang H, Gao X and Wang T: Eucommia ulmoides bark protects against renal injury in cadmium-challenged rats. J Med Food 15: 307-314, 2012.

26. Yin F, Liu J, Zheng X, Guo L and Xiao H: Geniposide induces the expression of heme oxygenase-1 via PI3K/Nrf2-signaling to enhance the antioxidant capacity in primary hippocampal neurons. Biol Pharm Bull 33: 1841-1846, 2010.
27. Wang SW, Lai CY and Wang CJ: Inhibitory effect of geniposide on aflatoxin B1-induced DNA repair synthesis in primary cultured rat hepatocytes. Cancer Lett 65: 133-137, 1992.

28. Koo HJ, Lee S, Shin KH, Kim BC, Lim CJ and Park EH: Geniposide, an anti-angiogenic compound from the fruits of Gardenia jasminoides. Planta Med 70: 467-469, 2004

29. Wang J, Hou J, Zhang P, Li D, Zhang C and Liu J: Geniposide reduces inflammatory responses of oxygen-glucose deprived rat microglial cells via inhibition of the TLR4 signaling pathway. Neurochem Res 37: 2235-2248, 2012.

30. Wang J, Li D, Hou J and Lei H: Protective effects of geniposide and ginsenoside $\mathrm{Rg} 1$ combination treatment on rats following cerebral ischemia are mediated via microglial microRNA-155-5p inhibition. Mol Med Rep 17: 3186-3193, 2018.

31. Chang CH, Wu JB, Yang JS, Lai YJ, Su CH, Lu CC and Hsu YM: The suppressive effects of geniposide and genipin on helicobacter pylori infections in vitro and in vivo. J Food Sci 82: 3021-3028, 2017.

32. Ha H, Ho J, Shin S, Kim H, Koo S, Kim IH and Kim C: Effects of eucommiae cortex on osteoblast-like cell proliferation and osteoclast inhibition. Arch Pharm Res 26: 929-936, 2003.

33. Lin J, Fan YJ, Mehl C, Zhu JJ, Chen H, Jin LY, Xu JH and Wang HM: Eucommia ulmoides Oliv. antagonizes $\mathrm{H}_{2} \mathrm{O}_{2}$-induced rat osteoblastic MC3T3-E1 apoptosis by inhibiting expressions of caspases 3,6,7 and 9. J Zhejiang Univ Sci B 12: 47-54, 2011.

34. Liu J, Yin F, Zheng X, Jing $\mathrm{J}$ and $\mathrm{Hu}$ Y: Geniposide, a novel agonist for GLP-1 receptor, prevents PC12 cells from oxidative damage via MAP kinase pathway. Neurochem Int 51: 361-369, 2007.

35. Chen Y, Zhang H, Li YX, Cai L, Huang J, Zhao C, Jia L, Buchanan R, Yang T and Jiang LJ: Crocin and geniposide profiles and radical scavenging activity of gardenia fruits (Gardenia jasminoides Ellis) from different cultivars and at the various stages of maturation. Fitoterapia 81: 269-273, 2010.

36. Lee P, Lee J, Choi SY, Lee SE, Lee S and Son D: Geniposide from Gardenia jasminoides attenuates neuronal cell death in oxygen and glucose deprivation-exposed rat hippocampal slice culture. Biol Pharm Bull 29: 174-176, 2006.

37. Cheng F, Ma C, Sun L, Zhang X, Zhai C, Li C, Zhang S, Ren B, Liu S, Liu S, et al: Synergistic neuroprotective effects of Geniposide and ursodeoxycholic acid in hypoxia-reoxygenation injury in SH-SY5Y cells. Exp Ther Med 15: 320-326, 2018.

38. Hu KH, Li WX, Sun MY, Zhang SB, Fan CX, Wu Q, Zhu W and $\mathrm{Xu}$ X: Cadmium induced apoptosis in MG63 cells by increasing ROS, activation of p38 MAPK and inhibition of ERK 1/2 Pathways. Cell Physiol Biochem 36: 642-654, 2015.

39. Pathak $N$ and Khandelwal S: Influence of cadmium on murine thymocytes: Potentiation of apoptosis and oxidative stress. Toxicol Lett 165: 121-132, 2006.

40. Livak KJ and Schmittgen TD: Analysis of relative gene expression data using real-time quantitative PCR and the 2(-Delta Delta C(T)) method. Methods 25: 402-408, 2001

41. Theoleyre S, Wittrant Y, Tat SK, Fortun Y, Redini F and Heymann D: The molecular triad OPG/RANK/RANKL: Involvement in the orchestration of pathophysiological bone remodeling. Cytokine Growth Factor Rev 15: 457-475, 2004.

42. Roodman GD: Treatment strategies for bone disease. Bone Marrow Transplant 40: 1139-1146, 2007.

43. Levesque M, Martineau C, Jumarie C and Moreau R Characterization of cadmium uptake and cytotoxicity in human osteoblast-like MG-63 cells. Toxicol Appl Pharmacol 231: 308-317, 2008.

44. Nakashima K, Zhou X, Kunkel G, Zhang Z, Deng JM, Behringer RR and de Crombrugghe $B$ : The novel zinc finger-containing transcription factor osterix is required for osteoblast differentiation and bone formation. Cell 108: 17-29, 2002.

45. Valois AA and Webster WS: The choroid plexus as a target site for cadmium toxicity following chronic exposure in the adult mouse: An ultrastructural study. Toxicology 55: 193-205, 1989.

46. Jamall IS, Naik M, Sprowls JJ and Trombetta LD: A comparison of the effects of dietary cadmium on heart and kidney antioxidant enzymes: evidence for the greater vulnerability of the heart to cadmium toxicity. J Appl Toxicol 9: 339-345, 1989.

47. Liu E, Han L, Wang J, He W Shang H, Gao X and Wang T: Eucommia ulmoides bark protects against renal injury in cadmium-challenged rats. J Med Food 15: 307-314, 2012. 
48. Pan YX, Luo Z, Zhuo MQ, Wei CC, Chen GH and Song YF: Oxidative stress and mitochondrial dysfunction mediated Cd-induced hepatic lipid accumulation in zebrafish Danio rerio. Aquat Toxicol 199: 12-20, 2018.

49. Mao T, Han C, Wei B, Zhao L, Zhang Q, Deng R, Liu J, Luo Y and Zhang Y: Protective effects of quercetin against cadmium chloride-induced oxidative injury in goat sperm and zygotes. Biol Trace Elem Res 185: 344-355, 2018.

50. Wongmekiat O, Peerapanyasut W and Kobroob A: Catechin supplementation prevents kidney damage in rats repeatedly exposed to cadmium through mitochondrial protection. Naunyn Schmiedebergs Arch Pharmacol 391: 385-394, 2018.

51. Qu Y, Liu Y, Chen L, Zhu Y, Xiao X, Wang D and Zhu Y: Nobiletin prevents cadmium-induced neuronal apoptosis by inhibiting reactive oxygen species and modulating JNK/ERK1/2 and Akt/mTOR networks in rats. Neurol Res 40: 211-220, 2018.

52. Kováčik J, Dresler S, Peterková V and Babula P: Metal-induced oxidative stress in terrestrial macrolichens. Chemosphere 203: 402-409, 2018

53. Varricchi G, Ameri P, Cadeddu C, Ghigo A, Madonna R, Marone G, Mercurio V, Monte I, Novo G, Parrella P, et al: Antineoplastic drug-induced cardiotoxicity: A redox perspective. Front Physiol 9: 167, 2018.

54. Kim J, Kwon WS, Rahman MS, Lee JS, Yoon SJ, Park YJ, You YA and Pang MG: Effect of sodium fluoride on male mouse fertility. Andrology 3: 544-551, 2015.

55. Chatterjee S, Kundu S, Sengupta S and Bhattacharyya A: Divergence to apoptosis from ROS induced cell cycle arrest: Effect of cadmium. Mutat Res 663: 22-31, 2009.
56. Wang SH, Shih YL, Kuo TC, Ko WC and Shih CM: Cadmium toxicity toward autophagy through ROS-activated GSK-3beta in mesangial cells. Toxicol Sci 108: 124-131, 2009.

57. Sporn MB and Liby KT: NRF2 and cancer: The good, the bad and the importance of context. Nat Rev Cancer 12: 564-571, 2012.

58. Ishii T, Itoh K, Takahashi S, Sato H, Yanagawa T, Katoh Y, Bannai S and Yamamoto M: Transcription factor Nrf2 coordinately regulates a group of oxidative stress-inducible genes in macrophages. J Biol Chem 275: 16023-16029, 2000.

59. Lee IT, Wang SW, Lee CW, Chang CC, Lin CC, Luo SF and Yang CM: Lipoteichoic acid induces HO-1 expression via the TLR2/MyD88/c-Src/NADPH oxidase pathway and Nrf2 in human tracheal smooth muscle cells. J Immunol 181: 5098-5110, 2008.

60. Nguyen T, Sherratt PJ and Pickett CB: Regulatory mechanisms controlling gene expression mediated by the antioxidant response element. Annu Rev Pharmacol Toxicol 43: 233-260, 2003.

61. Khor TO, Huang MT, Prawan A, Liu Y, Hao X, Yu S, Cheung WK, Chan JY, Reddy BS, Yang CS and Kong AN: Increased susceptibility of Nrf2 knockout mice to colitis-associated colorectal cancer. Cancer Prev Res (Phila) 1: 187-191, 2008.

This work is licensed under a Creative Commons Attribution-NonCommercial-NoDerivatives 4.0 International (CC BY-NC-ND 4.0) License. 